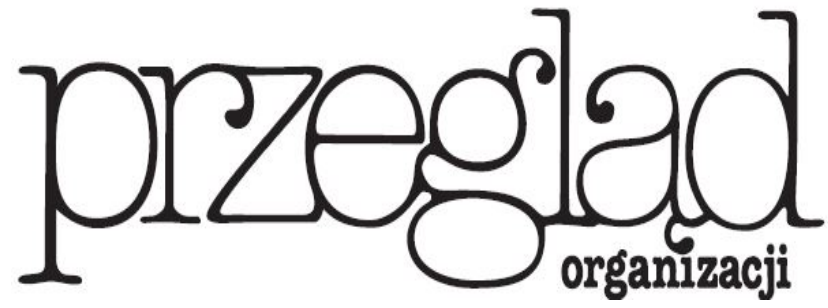

Miesięcznik TNOiK Założył Karol Adamiecki w 1926 r.

\title{
SPECYFIKA ORAZ PERSPEKTYWY ROZWOJU ORGANIZACJI W KOSMOSIE
}

https://doi.org/10.33141/po.2019.05.04

\section{Arnold Pabian, Barbara Pabian}

\section{Wprowadzenie}

K osmos stanowi nową przestrzeń dla tworzenia organizacji. Mikroorganizacje, utworzone przez człowieka, już funkcjonują w tym środowisku. Są to wieloosobowe załogi stacji orbitalnych, przebywajace $\mathrm{w}$ przestrzeni kosmicznej przez wiele miesięcy. Zostały one powołane do realizacji określonych celów, występuje w nich hierarchia władzy z wyraźnie wyodrębnionym stanowiskiem dowódcy, a także podział pracy. Dysponują wyposażeniem materialno-technicznym oraz technologicznym i korzystają z niego według ściśle ustalonych zasad. Obecnie są to wprawdzie niewielkie organizacje, funkcjonujące w skrajnie niekorzystnych dla człowieka warunkach, jednak szybki rozwój technik i technologii kosmicznych, a w szczególności planowane pionierskie przedsięwzięcia, prowadzić będzie do zwiększania się liczby oraz wielkości organizacji w kosmosie. Już teraz planuje się budowę stałej bazy na Księżycu oraz miasta na Marsie, prowadzenie
Przegląd Organizacji, Nr 5 (952), 2019, ss. 25-31 www.przegladorganizacji.pl @Towarzystwo Naukowe Organizacji i Kierownictwa (TNOiK) operacji wydobywczych na asteroidach, budowę stacji wokółksiężycowej, kosmicznych hoteli, a także elektrowni słonecznych. Wszystko to skłania do refleksji nad stanem, warunkami funkcjonowania i perspektywą rozwoju organizacji zlokalizowanych $\mathrm{w}$ przestrzeni kosmicznej. Rozpatrywanie tego rodzaju organizacji można uznać za pionierskie $z$ naukowego punktu widzenia. Nie znajduje ono odzwierciedlenia w literaturze naukowej, chociaż różne wątki tematyczne dotyczące kosmosu są w niej podejmowane. Ich przykładem są badania i koncepcje dotyczące: kosmicznego wyścigu mocarstw (Foo i in., 2015, s. 482-500), wykrywania anomalii i usterek w statkach kosmicznych (Kang, Pi, 2018, s. 435-451), zarządzania dostawą części zamiennych do stacji kosmicznej (Peres, Grenouilleau, 2002, s. 252-262), misji górniczych do asteroid (Probst i in., 2016, s. 458-470), żywności przeznaczonej do spożywania w kosmosie (Glew, 1980, s. 2-5). 
Głównym celem artykułu jest prezentacja specyfiki funkcjonowania organizacji w przestrzeni kosmicznej, warunków, które powinny spełniać ze względu na tę specyfikę w kontekście zarządzania, oraz perspektyw ich rozwoju. Praca w stanie nieważkości wykonywana jest w odmienny niż na Ziemi sposób. Wymaga szczególnej wiedzy i umiejętności, a także odpowiedniego stanu zdrowia i kondycji fizycznej. Warunki panujące w kosmosie stają się główną determinantą struktury i funkcjonowania organizacji, które będą wykonywały zadania zmierzające do coraz większej jego penetracji. Podstawę opracowania stanowią: kwerenda biblioteczna, monitoring stron internetowych, a także doświadczenia wyniesione $\mathrm{z}$ obserwacji prowadzonej w Centrum Przygotowania Kosmonautów im. J. Gagarina $\mathrm{w}$ Moskwie oraz rozmowa $\mathrm{z}$ Sergiejem Zaletinem - 92 kosmonautą Rosji.

\section{Krótka historia eksploracji kosmosu przez człowieka}

$\mathbf{P}$ race nad fizyczną eksploracją przestrzeni kosmicznej rozpoczęły się w pierwszych latach po II wojnie światowej. W tym zakresie konkurowały ze sobą ówczesne mocarstwa: Związek Socjalistycznych Republik Radzieckich oraz Stany Zjednoczone Ameryki Północnej. Podbój kosmosu zapoczątkowali Rosjanie, dokonując wystrzelenia dwóch sztucznych satelitów Ziemi (Sputnik 1 i Sputnik 2) z kosmodromu Bajkonur (1957 r.). W Sputniku 2 oraz w wystrzelonym w 1960 r. Sputniku 5 umieszczano psy o imionach Łajka oraz Biełka i Striełka (URL 1).

Zakończone sukcesem eksperymenty z udziałem zwierząt zapoczątkowały erę wysyłania ludzi w kosmos. W 1961 r. Jurij Gagarin jako pierwszy kosmonauta na świecie okrążył Ziemię na pokładzie załogowego statku Wostok, a dwa lata później w kosmos poleciała pierwsza kobieta - Walentina Tierieszkowa. Kolejnym ważnym osiągnięciem był spacer w otwartej przestrzeni kosmicznej, który odbył w 1965 r. Aleksiej Leonow (URL 2). Kilka lat później Rosjanie umieścili na orbicie okołoziemskiej stację kosmiczną Salut 1 (Zarja).

W tym czasie również Amerykanie realizowali pionierskie programy podboju kosmosu. Do najważniejszych można zaliczyć następujące przedsięwzięcia: Man in Space, Mercury, Gemini, Apollo. Ukoronowaniem tych wysiłków było lądowanie Amerykanów na Księżycu w 1969 r. (misja Apollo 11) (URL 3). Stany Zjednoczone, podobnie jak Związek Radziecki, ciągle udoskonalały technologie i techniki, poszukując nowych możliwości penetracji przestrzeni kosmicznej. Amerykańska działalność doprowadziła do umieszczenia na orbicie stacji Skylab, budowy wahadłowców, a także lądowania w 2004 r. łazika Opportunity na Marsie. W 1995 r. rozpoczęła się współpraca amerykańsko-rosyjska dotycząca lotów kosmicznych, W jej wyniku realizowano program Shuttle-Mir, obejmujący loty wahadłowców i rosyjskich pojazdów kosmicznych Sojuz na rosyjską stację orbitalną Mir (URL 4).
W XXI wieku również inne kraje zaczęły tworzyć i realizować programy kosmiczne. Na czoło rankingu wysunęły się: Chiny, Japonia oraz Indie. Chiny w 2003 r. wysłały w kosmos swój pierwszy statek załogowy Shenzhou, natomiast w 2008 r. chiński astronauta odbył spacer w przestrzeni kosmicznej. W 2007 r. Japończycy zrealizowali swoją pierwszą misję badania Księżyca. W 2008 r. Indie skierowały na Księżyc pierwszą bezzałogową sondę o nazwie Chandrayaan (URL 5).

Kolejne państwa nie tylko wykazują zainteresowanie kosmosem, lecz również realizują bardzo ambitne przedsięwzięcia. Według Organizacji Współpracy Gospodarczej i Rozwoju (OECD), obecnie ponad 60 krajów ma satelity na orbicie (URL 6). Planuje się budowę stałej bazy na Księżycu oraz miasta na Marsie. „Lot załogowy pierwotnie był przewidywany na 2023 r., lecz obecnie został przesunięty na rok 2025, wtedy to na Marsie ma powstać pierwsza zamieszkana osada. Mars One przyjął już zgłoszenia ponad 200 tys. chętnych" (Łoboda, 2015, s. 292). W 2033 r. NASA zamierza wysłać na Marsa człowieka w celu tworzenia pozaziemskiej kolonii. Największą aktywność w zakresie podboju kosmosu wykazują Chiny. Planują one między innymi następujące przedsięwzięcia:

a) prowadzenie operacji wydobywczych na asteroidach przez maszyny napędzane energią jądrową,

b) budowę elektrowni słonecznych w kosmosie,

c) uruchomienie suborbitalnego transportowca, który

będzie przewozić astronautów na Księżyc i sprowadzać próbki z Marsa (URL 7).

Przestrzeń kosmiczna staje się dostępna już nie tylko dla astronautów, lecz również dla ludzi, którzy astronautami nie są i którzy dotychczas nie mieli styczności z technikami i technologiami kosmicznymi. Dobry przykład stanowi turystyka kosmiczna. Zaczęła się ona rozwijać na początku XXI wieku. W 2001 r. odbył się pierwszy lot komercyjny przy użyciu rosyjskich statków Sojuz na Międzynarodową Stację Kosmiczną, który został zorganizowany przez Space Adventures. Pierwszym kosmicznym turystą był Dennis Tito, amerykański miliarder, który przebywał w kosmosie przez 10 dni. Podróż ta kosztowała go $20 \mathrm{mln}$ dolarów. Rok później powtórzył ten wyczyn milioner Mark Shuttleworth z Republiki Południowej Afryki. Oprócz uprawiania turystyki kosmicznej wykonał on prace eksperymentalne dotyczące nowej generacji leku przeciwnowotworowego. Prawdziwy przełom w turystyce kosmicznej nastąpił jednak w 2004 roku, kiedy to prywatny samolot rakietowy SpaceShipOne z obciążeniem imitującym obecność dwóch pasażerów przekroczył granice kosmosu na wysokość ponad 100 km (Pabian, Pabian, 2011, s. 11). Następnymi turystami kosmicznymi byli: Anousheh Ansari (uczestniczyła w 2007 roku w 10-dniowej misji orbitalnej), Charles Simonyi, były dyrektor wykonawczy Microsoft (przebywal w kosmosie dwukrotnie, tj. w latach 2007 i 2009), Richard Garriott - deweloper gier (odbył wyprawę kosmiczną w 2008 r.), Guy Laliberte, kanadyjski założyciel Cirque du Soleil (poleciał w kosmos w 2009 r.). 
Jedną z największych i najbardziej innowacyjnych kompanii w sektorze pasażerskich lotów kosmicznych jest obecnie firma Virgin Galactic. Założył ją Richard Branson. Zamierza on w najbliższych latach organizować turystyczne loty suborbitalne. Kluczową rolę w tym przedsięwzięciu odgrywa The Spaceship Company, zajmująca się projektowaniem i montażem statków kosmicznych dla Virgin Galactic.

Pionierskim przedsięwzięciem w obszarze turystyki kosmicznej są hotele kosmiczne, w których turyści będą przebywać w stanie nieważkości. Do końca 2021 roku ma powstać $320 \mathrm{~km}$ nad Ziemią hotelowa kapsuła Aurora Station, w której będzie mogło jednorazowo przebywać sześć osób: czterech turystów oraz dwóch członków załogi. Koszt 12-dniowego pobytu (w cenie uwzględniono transport z Ziemi, zakwaterowanie, wyżywienie i powrót) wyniesie 9,5 mln USD. Podróż będzie możliwa po odbyciu 3-miesięcznego szkolenia (URL 8).

\section{Otoczenie i specyfika organizacji zlokalizowanych w kosmosie}

W kosmosie, a więc na umownej wysokości powyżej $100 \mathrm{~km}$ od powierzchni Ziemi, przebywa coraz więcej wieloosobowych zespołów, które mają cechy organizacji. Są to załogi stacji orbitalnych oraz statków kosmicznych. Ekspedycje, przebywające na Międzynarodowej Stacji Kosmicznej od 2009 roku, składają się zwykle z 6 osób, a czas pobytu w kosmosie większości z nich przekracza 150 dni. W locie kosmicznym, zorganizowanym przez USA, RFN i Holandię w okresie 30.10.1985-6.11.1985 (STS-61-A), brało udział 8 kosmonautów.

Realizacja różnego rodzaju przedsięwzięć wymaga pracy zespołowej ukierunkowanej na ściśle określone cele, podziału zadań oraz przywództwa. Załogi stacji orbitalnych oraz statków kosmicznych spełniają te kryteria, a więc stanowią mikroorganizacje funkcjonujące w skrajnie odmiennym od ziemskiego środowisku. Te wieloosobowe załogi posiadają następujące cechy organizacji:

a) zostały powołane do realizacji określonych celów, np. prowadzenia eksperymentów na orbicie,

b) tworzą je ludzie, wykonujący zadania wynikające z podziału pracy,

c) obowiązuje w nich hierarchia władzy, odpowiadająca sformalizowanej strukturze organizacyjnej; na stacjach kosmicznych członkowie załogi pełnią funkcje dowódców, inżynierów pokładowych, pracowników naukowych, dowódców statków ratowniczych,

d) wyodrębniony jest w nich ośrodek władzy, zwykle jednoosobowy w osobie dowódcy,

e) dysponują konkretnym wyposażeniem materialno-technicznym oraz technologicznym oraz posługują się nim według ściśle ustalonych zasad.

Praca w organizacjach kosmicznych wymaga unikalnej wiedzy i umiejętności oraz doskonałego stanu zdrowia. $\mathrm{Na}$ pokładzie stacji kosmicznej utrzymywany jest stan nieważkości, co znacznie utrudnia pracę oraz odpoczynek. Obecnie praca ta trwa od około 8 do 12 godzin na dobę. Oprócz niej trzeba wykonywać obowiązkowe ćwiczenia fizyczne, co zapobiega negatywnemu oddziaływaniu mikrograwitacji na organizm kosmonauty. W jej wyniku dochodzić może do rozciągania się ciała włącznie z kręgosłupem, kurczenia, a nawet zaniku mięśni, opuchlizny twarzy, zaburzenia cyklów dziennych i nocnych, poczucia dezorientacji. Nie tylko więc praca, wynikająca z celów ekspedycji, sprawia wiele trudności, lecz również codzienne czynności, takie jak: spanie, mycie się, spożywanie posiłków i napojów, a nawet załatwianie potrzeb fizjologicznych ${ }^{1}$. W warunkach kosmicznych szczególnego znaczenia nabiera więc sformułowana przez R. Templar (2015, s. 122) reguła właściwego zarządzania swoim zdrowiem (manage your health).

Organizacja kosmiczna funkcjonuje w niewielkiej, ograniczonej ścianami stacji lub pojeździe, które uniemożliwiają jej członkom kontakt wzrokowy ze środowiskiem zewnętrznym. Kontakt ten jest możliwy tylko i wyłącznie za pośrednictwem urządzeń elektronicznych. Członkowie tego typu organizacji zamknięci są przez długi czas w pojeździe kosmicznym, odizolowani od ziemskiego otoczenia, od swoich rodzin, pozbawieni możliwości życia i działania w sposób, do którego byli przyzwyczajeni na Ziemi. Dlatego tak istotne jest zdrowie psychiczne członków tego typu organizacji. N. Thompson (2013, s. 287) wyszczególnia następujące źródła złego stanu zdrowia psychicznego pracowników: niepokój (anxiety), nerwica natręctw (obsessive compulsive disorder), zaburzenia jedzenia (eating disorders), depresja (depression), zespół stresu pourazowego (post-traumatic stress disorder), choroba dwubiegunowa afektywna (bipolar disorder), schizofrenia (schizophrenia). Obciążenie psychiczne członków organizacji kosmicznych jest szczególnie duże ze względu na wysoki stopień ryzyka przedsięwzięć kosmicznych i co się z tym wiąże - znaczne zagrożenie życia i zdrowia ich uczestników. Są oni więc szczególnie narażeni na występowanie różnego rodzaju zaburzeń psychicznych, które mogą zagrażać misji. Aby zminimalizować ryzyko z tym związane, wskazany jest werbunek ludzi o szczególnie wysokiej odporności psychicznej, a także dalsze jej wzmacnianie poprzez trening i różnego rodzaju ćwiczenia.

Obecne, zlokalizowane w kosmosie organizacje, ze względu na swoje niewielkie rozmiary, posiadają proste formalne struktury organizacyjne typu liniowego. Oparte są one na podziale pracy wynikającym ze specjalizacji jej członków. Dzięki temu, jak podkreślają R. Daft, D. Marcic (2013, s. 235), praca może być wykonywana lepiej i wydajniej. Specjalizacja pracy (work specialization) czasami zwana podziałem pracy (division of labor) to według nich stopień, w jakim organizacyjne zadania są podzielone na oddzielne części do wykonania. $\mathrm{Z}$ tworzeniem i funkcjonowaniem struktur organizacyjnych wiąże się także departamentalizacja (departmentalization), będąca podstawą do grupowania stanowisk w działy, a działy w całą organizację. Obecnie nie ma ona zastosowania w organizacjach kosmicznych. Ich struktury organizacyjne zawierają bowiem zbyt małą liczbę stanowisk pracy, aby kwalifikowały się do łączenia w działy. Departamentalizacja będzie nabierała coraz większego znaczenia w miarę powiększania się tego typu organizacji. Również 
komunikacja (przekazywanie i odbiór informacji), a także koordynacja działań wewnątrz organizacji kosmicznej nie stanowi problemu. Kosmonautów jest niewielu i są oni zlokalizowani w niewielkiej przestrzeni ograniczonej ścianami pojazdu kosmicznego. Problemy mogą natomiast powstawać $\mathrm{w}$ kontaktach kosmonautów z centralą naziemną, np. na skutek utraty łączności lub awarii urządzeń, dzięki której jest ona możliwa. Sergiej Zaletin stwierdził, że kosmonauci powinni być tak dobrze dobrani i wyszkoleni, aby byli w stanie radzić sobie w kosmosie w różnego rodzaju sytuacjach bez udziału i pomocy operatorów z Ziemi. Oczywiście nie dotyczy to wyjątkowych sytuacji zagrażających życiu i zdrowiu kosmonautów.

Organizacje kosmiczne cechuje wysoki stopień formalizacji działań. Ich załoga ma obowiązek przestrzegania ściśle określonych procedur i harmonogramów. Harmonogramy mogą być oparte na minutowych skalach czasu, co oznacza konieczność wykonywania przydzielonych zadań z dokładnością co do minuty, a nawet sekundy.

Oprócz formalnej organizacji ważna jest również organizacja nieformalna. Organizację nieformalną (informal organization), jak twierdzi A. Ghillyer (2009, s. 178), stanowi agregacja osobistych kontaktów, interakcji i powiązań grup osób pracujących $\mathrm{w}$ formalnej organizacji. $\mathrm{W}$ przypadku doboru ludzi do pracy $\mathrm{w}$ organizacjach kosmicznych istotne jest wzięcie pod uwagę tego właśnie aspektu ich funkcjonowania. Osobiste kontakty, interakcje i powiązania, występujące między członkami ekspedycji kosmicznych, mogą bowiem wpływać pozytywnie lub negatywnie na funkcjonowanie organizacji formalnej. Dlatego choć nie jest to zwykle praktykowane w organizacjach ziemskich, postuluje się rozpoznanie tego rodzaju kontaktów, interakcji i powiązań, opracowanie diagnozy i przeprowadzenie symulacji odpowiadającej na pytanie: jak kształtować się będzie organizacja nieformalna podczas pobytu kosmonautów w przestrzeni kosmicznej? Jeżeli symulacja wykaże, że mogą powstawać konflikty, nieporozumienia, szkodliwe współzawodnictwo i inne negatywne zjawiska, wskazana jest zmiana składu osobowego zespołu, a jeżeli to nie jest możliwe, omówienie z jego członkami potencjalnych problemów i niebezpieczeństw, a także poddanie ich odpowiednim szkoleniom.

Organizacje kosmiczne dysponują kosztownym i unikalnym wyposażeniem, którego budowa i działanie dostosowane są do warunków panujących w kosmosie. Zlokalizowane jest ono w modułach stacji o różnym przeznaczeniu. Wytworem działalności organizacji kosmicznych są obecnie przede wszystkim wyniki badań (eksperymentów, obserwacji, pomiarów), a także dostarczane na Ziemię próbki ciał niebieskich. Aby organizacje te mogły funkcjonować przez dłuższy czas na orbicie ziemskiej lub poza nią, muszą być zaopatrywane w różne produkty, dostarczane przez specjalnie statki transportowe (np. artykuły żywnościowe, części zamienne, aparaturę naukową). Od 2008 r. loty zaopatrzeniowe wykonywały głównie statki noszące nazwy ATV i HTV.

Organizacje kosmiczne funkcjonują $\mathrm{w}$ otoczeniu całkowicie odmiennym od ziemskiego. Stanowi je nieprzyjazna dla człowieka przestrzeń kosmiczna. Powyżej 100 km nad powierzchnią Ziemi, a więc tam gdzie rozpoczyna się kosmos, występuje próżnia, w której nie rozchodzą się fale dźwiękowe oraz utrudniona jest wymiana ciepła. $W$ przestrzeni kosmicznej obecne jest ponadto promieniowanie kosmiczne szkodliwe dla człowieka, a także skrajnie wysokie i niskie temperatury, wywołane bezpośrednim działaniem promieni słonecznych lub ich brakiem, który występuje $\mathrm{w}$ cieniu planet. Człowiek, znajdujący się w próżni bez odpowiedniego skafandra, umiera po kilku/ kilkunastu sekundach (zależy od odporności organizmu) wskutek utraty tlenu $\mathrm{z}$ organizmu i ustania pracy serca. Ludzie, pracujący $\mathrm{w}$ organizacjach kosmicznych, są więc znacznie bardziej narażeni na różne wypadki zagrażające ich zdrowiu i życiu. G. Dessler (2011, s. 616) prezentuje następującą listę uwarunkowań, które mogą być źródłem wypadków w warunkach ziemskich: niewłaściwe zabezpieczenie sprzętu, wadliwe wyposażenie, niewłaściwe procedury, przeciążenie maszyn, niewłaściwe oświetlenie, niewłaściwa wentylacja (niewystarczająca wymiana powietrza, zanieczyszczone źródło powietrza). W kosmosie największym zagrożeniem są awarie pojazdów kosmicznych i wyposażenia spowodowane czynnikami zewnętrznymi lub błędami człowieka, od których zależy zdrowie i życie kosmonautów, a także ich powrót na Ziemię. Stacje i statki kosmiczne narażone są między innymi na niszczące działanie okruchów skalnych i odpadków kosmicznych. Awarie mogą być spowodowane wyciekami toksycznych substancji lub usterkami w działaniu skafandrów kosmicznych. Przykładem może być nieudany spacer kosmiczny Luca Parmiatano, podczas którego w hełmie kosmonauty zaczęła gromadzić się woda. Tylko i wyłącznie szybka reakcja kolegi i decyzje kontrolerów naziemnych zdołały uratować mu życie.

Organizacje, funkcjonujące w kosmosie, coraz częściej składają się z ludzi o różnej narodowości. Przykładowo w składach ostatnich stałych załóg Międzynarodowej Stacji Kosmicznej (International Space Station), którym nadano numery od 51 do 59 wchodzili: Amerykanie, Rosjanie, Francuzi, Włosi, Japończycy, Niemcy, Kanadyjczycy. Oznacza to konieczność uwzględniania w szkoleniach kosmonautów różnic kulturowych. Nieznajomość różnic kulturowych może zakłócać werbalną i niewerbalną komunikację między nimi, prowadzić do niewłaściwej interpretacji zachowań i w konsekwencji do błędów w różnych sferach życia w pojazdach kosmicznych. Różnice kulturowe rozpatruje się między innymi w następujących układach: indywidualizm - kolektywizm, męskość - żeńskość, tolerancja niepewności, dystans wobec władzy, niski - wysoki kontekst, wycinkowość - całościowość, powściągliwość - ekspresyjność, przyzwolenie - restrykcyjność, uniwersalność - partykularyzm, ceremonialność - nieceremonialność, stosunek do czasu, cele odległe - cele bliskie, wewnątrzsterowność - zewnątrzsterowność (Pabian, Pabian, 2019, s. 27-37). Zarządzanie międzynarodową organizacją kosmiczną z pewnością ułatwiają transkulturowe kompetencje (transcultural competence) jej pracowników. Jak konstatują J. Glover, L. Friedman (2015, s. 8-9), jest to zdolność do skutecznego radzenia sobie $\mathrm{z}$ problemami, wynikającymi z różnic kulturowych w każ- 
dym kulturowym otoczeniu. Posiadanie transkulturowych kompetencji umożliwia rozpoznawanie, poszanowanie, znajdowanie kompromisów i realizację działań, mających na celu łagodzenie kulturowych dylematów. Istotne jest również posiadanie cechy, którą J. Comfort, P. Franklin (2014, s. 4) nazywają mindfulness (kulturowa wrażliwość). To stan świadomości, w którym jest możliwe świadome lub nieświadome wykorzystanie wiedzy, umiejętności i postaw które są potrzebne, aby efektywnie i właściwie pozostawać w interakcjach $\mathrm{z}$ innymi kulturami.

Dowódcy stacji i statków kosmicznych w rozumieniu nauk o zarządzaniu pełnią funkcje kierownicze. Ze względu na warunki, w których działają, można ich nazwać, używając terminologii stosowanej przez Ch. Achua, R. Lussier (2010, s. 299), liderami o orientacji na wysokie ryzyko (high risk orientation). Rację mają G. Jones i J. George (2011, s. 225), że im bardziej zmienne i niepewne jest zewnętrzne środowisko organizacji (external organizational environment), tym większe są problemy, w obliczu których stają kierownicy. W przypadku dowódców organizacji kosmicznych umiejętność szybkiego i sprawnego rozwiązywania problemów w wielu przypadkach decyduje o życiu i zdrowiu członków ekspedycji. Dlatego muszą być oni proaktywni, a nie reaktywni (proactive, not reactive). Jak słusznie ocenia R. Templar (2015, s. 94), jeżeli kierownik nie jest proaktywny, to pozostaje w stagnacji.

Szczególne umiejętności kierownicze powinny posiadać osoby przygotowujące przedsięwzięcia kosmiczne oraz zarządzające nimi $\mathrm{z}$ poziomu central naziemnych. Zarządzanie odnosi się do postępowania z ludźmi, wyposażeniem i innym majątkiem (nie mniej ważnymi aktywami finansowymi) w kontekście organizacyjnym i ekonomicznym (Tengblad, 2017, s. 325). Tak pojęte zarządzanie, w tym także projektami i ekspedycjami kosmicznymi, wymaga posiadania wiedzy i umiejętności z zakresu wszystkich funkcji zarządzania, do których zalicza się planowanie, organizowanie, przywództwo, w tym motywowanie oraz kontrolę (planning, organizing, leading/influencing/staffing, controlling). Funkcje te szeroko opisali w literaturze między innymi: A. Ghillyer (2009, s. 109-364), S. Certo, T. Certo (2009, s. 179-570), L. Rue, L. Byars (2009, s. 129-407), R. Lussier (2009, s. 84-522),

R. Daft, D. Marcic (2013, s. 158-600).

Dzięki właściwemu ich wypełnianiu eliminuje się niedoskonałości zarządzania i minimalizuje prawdopodobieństwo niepowodzeń w tej sferze. N. Douglas, T. Wykowski (2017, s. 27-28) utożsamiają ważniejsze niedoskonałości i niepowodzenia zarządzania z następującymi czynnikami: rozmyte koncepcje, pycha i iluzja kontroli, niejednoznaczny cel, słabo rozwinięta wrażliwość etyczna. Nabyte umiejętności kierownicze w powiązaniu $\mathrm{z}$ odpowiednią intuicją i talentem ułatwiają znajdowanie odpowiednich ludzi do właściwego wykonywania zadań w kosmosie, a następnie sprawne i efektywne przygotowanie planowanych ekspedycji. Ułatwiają również wprowadzanie zmian i innowacji. Trzeba zgodzić się z opinią R. Dafta i A. Bensona (2016, s. 343), że każda organizacja, a więc także zajmująca się wysyłaniem ludzi w kosmos, musi zmieniać się i wprowadzać innowacje.

\section{Kierunki rozwoju organizacji w kosmosie}

0 becną fazę rozwoju organizacji w kosmosie autorzy tego artykułu nazywają fazą pionierską (fazą wstępnego rozwoju). Jej charakterystyczne cechy to: bliska penetracja kosmosu z bezpośrednim udziałem człowieka, niewielka liczba przedsięwzięć kosmicznych, niewielka liczba oraz liczebność organizacji funkcjonujących w kosmosie. W miarę rozwoju technik i technologii kosmicznych nastąpi przejście do fazy szybkiego rozwoju: rozpocznie się era dalekich misji kosmicznych, zwiększy się asortyment i zakres prac wykonywanych w kosmosie, wzrośnie liczba i wielkość organizacji, które te prace będą wykonywać. Fazy dojrzałości i spadku wydają się bardzo odległe, o ile w ogóle możliwe kiedykolwiek do osiągnięcia, co wynika z ogromu wszechświata i licznych barier utrudniających jego pełną penetrację.

Kierunki i szybkość rozwoju organizacji w kosmosie będą zależeć od postępu w sferze technik i technologii kosmicznych. Już dziś plany największych projektantów i realizatorów programów kosmicznych są bardzo ambitne. NASA przygotowuje między innymi następujące przedsięwzięcia: budowę stacji wokółksiężycowej, która ma pełnić rolę bazy wypadowej w Daleki Kosmos (Deep Space Gateway) oraz załogowy, trwający 1000 dni, przelot w pobliże Marsa. Następne loty będą miały na celu lądowanie na tej planecie i dalszą jej eksplorację (URL 9). Jak wcześniej wspomniano, planuje się budowę stałej bazy na Księżycu oraz miasta na Marsie, prowadzenie operacji wydobywczych na asteroidach, budowę elektrowni słonecznych w kosmosie. Odrębnym i dynamicznie rozwijającym się sektorem jest turystyka kosmiczna. Chociaż hotel kosmiczny nie jest jeszcze przygotowany na przyjęcie turystów, to powstała już ziemska infrastruktura, umożliwiająca starty pojazdów Virgin Galactic. Stanowi ją pierwszy w historii komercyjny port kosmiczny Spaceport America, zbudowany w stanie Nowy Meksyk w USA w latach 2006-2011. Planuje się budowę takich portów również $\mathrm{w}$ innych częściach świata, np. w Wielkiej Brytanii (URL 10).

Jak wynika $\mathrm{z}$ wykazu planowanych przedsięwzięć, obecność człowieka w kosmosie będzie wykazywać tendencję wzrostową. Zwiększy się również złożoność zadań, prowadzonych $\mathrm{w}$ przestrzeni kosmicznej. Ich wykonanie $\mathrm{w}$ coraz większym stopniu wymagać będzie pracy zespołowej przy udziale coraz większej liczby ludzi. Obecne mikroorganizacje o prostej strukturze i niewielkim składzie osobowym z czasem będą stawały się coraz większe, a ich struktury bardziej złożone. Przykładowo w dużym, wielomodułowym hotelu kosmicznym trzeba będzie zatrudnić wiele osób, przydzielając ich do komórek i jednostek organizacyjnych zaprojektowanej struktury organizacyjnej. Z upływem lat zacznie nabierać znaczenia depertamentalizacja. W większych organizacjach kosmicznych z dużą liczbą stanowisk pracy stanie się ona wręcz koniecznością.

Niemal pewny jest postęp w zakresie umiędzynarodowiania się organizacji kosmicznych. Coraz więcej 
państw ma aspiracje kosmiczne i bierze udział w różnego rodzaju przedsięwzięciach pozaziemskich. Ma to wpływ na składy osobowe ekspedycji kosmicznych, wśród których jest coraz więcej reprezentantów różnych państw. Szczególnie wysoki stopień umiędzynarodowienia wystąpi w przypadku turystyki kosmicznej. Ważna będzie więc znajomość różnic kulturowych i ich wykorzystanie w tworzeniu pozytywnych relacji między ludźmi pochodzącymi z różnych kręgów kulturowych.

Wraz $\mathrm{z}$ rozrastaniem się formalnych struktur organizacyjnych w kosmosie rozrastać się również będą towarzyszące im organizacje nieformalne. Im więcej stanowisk pracy w organizacji, tym większa powstanie sieć osobistych kontaktów, interakcji i powiązań między ludźmi zajmującymi te stanowiska. Aby uniknąć negatywnego wpływu organizacji nieformalnych na organizacje formalne, trzeba będzie udoskonalać metody, mające na celu rozpoznanie ich funkcjonowania w zamkniętej i wyizolowanej przestrzeni stacji i statków kosmicznych, a także możliwości wpływania na ich funkcjonowanie z powierzchni Ziemi.

Działalność człowieka w organizacjach kosmicznych w dalszym ciągu będzie wysoce sformalizowana, oparta na rygorystycznych procedurach. Każda czynność w przestrzeni kosmicznej powinna być wykonana precyzyjnie i bezbłędnie, co zapobiegnie awariom, wypadkom i co się z tym wiąże, utracie zdrowia i życia. Sposób wykonywania czynności w kosmosie jest nie tylko ściśle określony w instrukcjach, lecz również wielokrotnie przećwiczony przez kosmonautów na Ziemi.

Podobnie, jak obecnie, w dalszym ciągu priorytetowym celem będzie zapewnienie człowiekowi bezpieczeństwa w przestrzeni kosmicznej. Wraz z rozwojem technik i technologii pojazdy i urządzenia wykorzystywane przez organizacje kosmiczne będą coraz bardziej niezawodne, chroniąc ludzi coraz skuteczniej przed szkodliwym oddziaływaniem mikrograwitacji.

Każdy kandydat do pracy w kosmosie bez względu na rodzaj kwalifikacji zawodowych oraz pełnioną w organizacji kosmicznej funkcję, będzie musiał, tak jak obecnie, legitymować się doskonałym stanem zdrowia, sprawnością fizyczną i wysoką odpornością psychiczną. Dobra kondycja zdrowotna i odporność psychiczna stanowią przepustkę do udziału w specjalistycznych szkoleniach obejmujących między innymi treningi rotacji i przeciążeń, (także na symulatorach lotu) oraz treningi w wodzie, stanowiące przygotowanie do pracy w kosmosie. Postęp techniczny sprawi, że z coraz większa precyzją będzie można przeprowadzać testy służące ocenie stanu zdrowia, kondycji i odporności psychicznej kandydatów do podróży kosmicznych.

Efektem pracy kosmonautów przestaną być z czasem tylko i wyłącznie wyniki badań oraz pobrane próbki $z$ różnych ciał niebieskich. Organizacje kosmiczne będą dostarczać na Ziemię surowce czerpane $\mathrm{z}$ asteroid oraz energię z elektrowni kosmicznych (przedsięwzięcia planowane przez Chińczyków).

Jednym z kluczowych problemów stanie się niezawodność, bezpieczeństwo i zasięg maszyn transpor- towych, dostarczających ludzi oraz produkty i sprzęt kosmicznym organizacjom.

$\mathrm{Z}$ czasem postanowienia Traktatu o przestrzeni kosmicznej mogą okazać się niewystarczające. Tworzenie ludzkich osad na ciałach niebieskich, jak również prowadzenie na nich działalności wydobywczej, może pozostawać w sprzeczności z jego postanowieniem, według którego przestrzeń kosmiczna $\mathrm{z}$ jej ciałami niebieskimi nie może być zawłaszczana przez jakiekolwiek państwa.

\section{Podsumowanie}

D rzestrzeń kosmiczna staje się nowym miejscem funkcjonowania organizacji, tworzonych przez człowieka. Warunki w niej panujące są wyjątkowo nieprzyjazne dla ludzi, a więc działalność tego typu organizacji staje się wysoce ryzykowana. Tworzenie organizacji w kosmosie jest też niezwykle kosztowne. Kosztowna jest również rekrutacja, selekcja i szkolenie kandydatów na kosmonautów. Pomimo tych barier kosmos przestaje być domeną działania tylko i wyłącznie państw i ich rządowych przedstawicielstw. Do sfery tej coraz śmielej wkracza prywatny kapitał, czego przykładem jest Virgin Galactic oraz The Spaceship Company. Kosmos przestaje być również penetrowany wyłącznie przez zawodowych kosmonautów. W coraz większym stopniu staje się otwarty dla osób, które stać na opłacenie kosztownej podróży kosmicznej i które wykazują się dobrą kondycją fizyczno-psychiczną.

Obecna niewielka liczba i rozmiary organizacji, funkcjonujących w kosmosie, stwarzają ograniczone zapotrzebowanie na wiedzę i umiejętności z zakresu zarządzania, którego integralną częścią jest organizacja i organizowanie. Wzrost liczby i rozmiarów przedsięwzięć kosmicznych wymusi wzrost tego zapotrzebowania. Bez znajomości nowoczesnych metod i technik zarządzania nie będzie bowiem możliwe osiąganie w przestrzeni kosmicznej ambitnych celów naukowych, gospodarczych i turystycznych. Coraz intensywniejsza penetracja kosmosu stanowi nowe wyzwanie dla zarządzania. Zarządzanie organizacjami kosmicznymi stanie się w przyszłości ważnym obszarem nauk o zarządzaniu i jakości oraz inspiracją do odkrywania i wdrażania nowych, innowacyjnych rozwiązań.

\section{prof. dr hab. Arnold Pabian \\ Politechnika Częstochowska \\ Wydział Zarządzania \\ ORCID: 0000-0002-1224-9167 \\ e-mail: a.pabian@pcz.pl}

\author{
dr hab. Barbara Pabian, prof. UE \\ Uniwersytet Ekonomiczny w Katowicach \\ Wydział Zarządzania \\ ORCID: 0000-0003-3059-6733 \\ e-mail: barbara.pabian@ue.katowice.pl
}




\section{Przypis}

1) Kosmonauci śpią $w$ pozycji pionowej w specjalnym śpiworze przymocowanym do ściany, spożywają wyłącznie gotowe, specjalne posiłki, aby ugasić pragnienie, używają słomki włożonej do woreczka z napojem.

\section{Bibliografia}

[1] Achua Ch., Lussier R. (2010), Effective Leadership, South-Western Cengage Learning, United States.

[2] Certo S., Certo T. (2009), Modern Management. Concepts and Skills, Pearson Education International, London.

[3] Comfort J., Franklin P. (2014), The Mindful International Manager. How to Work Effectively Across Cultures, Kogan Page, London.

[4] Daft R., Benson A. (2016), Management, Cengage Learning, United States.

[5] Daft R., Marcic D. (2013), Management: The New Workpla$c e$, South-Western Cengage Learning, United States.

[6] Dessler G. (2011), Human Resource Management, Pearson, New York.

[7] Douglas N., Wykowski T. (2017), Rethinking Management, Polgrave Macmillan, Houston.

[8] Foo Ch., Wu W., Yu B. (2015), Integrating Knowledge and Aerospace: Modeling a Sima Qian's Future for the Possibility of the Chinese Overtaking the Americans in Outer Space, „Chinese Management Studies”, Vol. 9, No. 4, pp. 482-500.

[9] Ghillyer A. (2009), Management. A Real World Approach, McGraw-Hill, Boston.

[10] Glew G. (1980), Food in Space, „Nutrition \& Food Science”, Vol. 80, No. 3, pp. 2-5.

[11] Glover J., Friedman L. (2015), Transcultural Competence, American Psychological Association, Washington.

[12] Jones G., George J. (2011), Essentials of Contemporary Management, McGraw-Hill, Irwin, New York.

[13] Kang X., Pi D. (2018), A Data-driven Method of Health Monitoring for Spacecraft, „Aircraft Engineering and Aerospace", Vol. 90, No. 2, pp. 435-451.

[14] Lussier R. (2009), Management Fundamentals. Concepts. Applications. Sill Development, South-Western Cengage Learning, Australia.

[15] Łoboda J. (2015), Niektóre problemy rozwoju turystycznej przestrzeni kosmicznej, [w:] E. Bilska-Wodecka, I. Sołjan (red.), Geografia na przestrzeni wieków. Tradycja i współczesność, Profesorowi Antoniemu Jackowskiemu w 80. rocznicę urodzin, Wyd. IGiGP UJ. Kraków, s. 287-297.

[16] Pabian A., Pabian B. (2019), Wielokulturowość w szkolnictwie wyższym. Zarządzanie i komunikacja z cudzoziemcami $z$ perspektywy różnic kulturowych, Wyd. Naukowe PWN, Warszawa.

[17] Pabian A., Pabian B. (2011), Marketing turystycznych usług kosmicznych, [w:] A. Pabian (red.), Nowe kierunki, metody, techniki w zarzadzaniu i marketingu, Wydawnictwo Wydziału Zarządzania Politechniki Częstochowskiej, Częstochowa, s. 11-21.

[18] Peres F., Grenouilleau J. (2002), Initial Spare Parts Supply of an Orbital System, „Aircraft Engineering and Aerospace Technology", Vol. 74, No. 3, pp. 252-262.
[19] Probst A., Peytavi G., Eissfeller B., Forstner R. (2016), Mission Concept Selection for an Asteroid Mining Mission, „Aircraft Engineering and Aerospace Technology: An International Journal", Vol. 88, No. 3, pp. 458-470.

[20] Rue L., Byars L. (2009), Management. Skills and Application, McGraw-Hill, New York.

[21] Templar R. (2015), The Rules of Management. A Definitive Code for Managerial Success, Pearson, New York.

[22] Tengblad S. (2017), Management Practice and the Doing of Management, [w:] A. Wilkinson, S. Armstrong, M. Lounsbury (eds.), The Oxford Handbook of Management, Oxford University Press, United Kingdom, pp. 325-342.

[23] Thompson N. (2013), People Managament, Palgrave Macmillan, London.

[24] URL 1: http://www.kosmosnews.pl/artykul/49-28-2-1361/ bielka-i-strielka-pierwsi-psi-kosmonauci-ktorzypowrocili.html

[25] URL 2: http://www.national-geographic.pl/traveler/ wywiady/aleksiej-leonow-pogromca-gwiazd

[26] URL 3: https://kosmonauta.net/2016/07/maly-krok-dlaczlowieka-ale-wielki-skok-dla-ludzkosci/

[27] URL 4: NASA Facts https://spaceflight.nasa.gov/history/ shuttle-mir/references/documents/benefits.pdf

[28] URL 5: (http://www.tvn24.pl)(http://www.tvn24.pl)

[29] URL 6: http://www.oecd.org/futures/oecdspaceforum.htm

[30] URL 7: http://forsal.pl/artykuly/1086324,chiny-zbudujaelektrownie-w-kosmosie-ich-nuklearne-statki-bedaprzewozic-turystow-za-ok-20-lat.html

[31] URL 8: https://www.rp.pl/Biznes/304099944-Pierwszykosmiczny-hotel-Juz-mozna-rezerwowac-pokoje.html

[32] URL 9: http://www.urania.edu.pl/wiadomości/nasaprezentuje-plan-dalekich-misji-zalogowych-3240.html

[33] URL 10: https://inzynieria.com/wpis-branzy/wiadomosci/ 10/51701,w-wielkiej-brytanii-powstanie-kosmodrom

\section{Specification and Development Perspectives of Organisation in Space}

\section{Summary}

Space exploration by humans is accelerating. It is planned to build a permanent base on the Moon and a city on the Mars. People want to conduct mining operations on asteroids, build a lunar station circulating the Moon, a space hotel and solar power plants. More and more people live and work in teams in space. Multi-person crews of orbital space stations carry out specific goals. There is a hierarchy of power with a clearly distinguished position of the commander and division of labour among the crew members. They have special equipment and often stay in orbit for many weeks. All these factors mean that these are organizations that operate in extremely unfavourable conditions. Cosmic conditions affect all aspects of their functioning. The article presents the specificity as well as development perspectives of organisations located in space.

\section{Keywords}

organisations, outer space 